\title{
Mandibular growth and dentoalveolar development in the treatment of Class II, division 1, malocclusion using Balters Bionator according to the skeletal maturation
}

\author{
Paulo Roberto dos Santos-Pinto는 Lídia Parsekian Martins², Ary dos Santos-Pinto ${ }^{3}$, Luiz Gonzaga Gandini Júnior ${ }^{3}$ \\ Dirceu Barnabé Raveli³, Cristiane Celli Matheus dos Santos-Pinto ${ }^{4}$
}

\begin{abstract}
Objective: The purpose of the study was to evaluate the influence of the skeletal maturation in the mandibular and dentoalveolar growth and development during the Class II, division 1, malocclusion correction with Balters bionator. Methods: Three groups of children with Class II, division 1, malocclusion were evaluated. Two of them were treated for one year with the bionator of Balters appliance in different skeletal ages (Group 1: 6 children, 7 to 8 years old and Group 2: 10 children, 9 to 10 years old) and the other one was followed without treatment (Control Group: 7 children, 8 to 9 years old). Lateral 45 degree cephalometric radiographs were used for the evaluation of the mandibular growth and dentoalveolar development. Tantalum metallic implants were used as fixed and stable references for radiograph superimposition and data acquisition. Student's t test was used in the statistical analysis of the displacement of the points in the condyle, ramus, mandibular base and dental points. Analysis of variance one-fixed criteria was used to evaluate group differences (95\% of level of significance). Results: The intragroup evaluation showed that all groups present significant skeletal growth for all points analyzed (1.2 to $3.7 \mathrm{~mm}$ ), but in an intergroup comparison, the increment of the mandibular growth in the condyle, ramus and mandibular base were not statically different. For the dentoalveolar modifications, the less mature children showed greater labial inclination of the lower incisors $(1.86 \mathrm{~mm})$ and the most mature children showed greater first permanent molar extrusion $(4.8 \mathrm{~mm})$.
\end{abstract}

Keywords: Angle Class II malocclusion. Orthopedics. Growth and development.

Objetivo: avaliar a influência da maturação óssea no processo de crescimento e de desenvolvimento mandibular e dentoalveolar durante a correção da Classe II, divisão 1, com o Bionator de Balters. Métodos: foram avaliados três grupos de crianças com Classe II, divisão 1. Dois grupos foram tratados por um ano com o aparelho Bionator de Balters, em diferentes idades esqueléticas (Grupo 1: 6 crianças, com 7 a 8 anos de idade; e Grupo 2: 10 crianças, com 9 a 10 anos); e um grupo sem tratamento (Grupo controle: 7 crianças, com 8 a 9 anos). Telerradiografias laterais em norma de $45^{\circ}$ foram utilizadas para a avaliação do crescimento mandibular e para o desenvolvimento dentoalveolar. Implantes metálicos de tântalo foram usados como referência fixa e estável para sobreposições radiográficas e aquisição de dados. Na análise estatística do deslocamento de pontos localizados na região de côndilo, corpo e base mandibular e de pontos dentários, foi empregado o teste $t$ de Student; para avaliar as diferenças entre os grupos, usou-se a análise de variância a um critério de classificação (nível de significância de 95\%). Resultados: os grupos, quando avaliados individualmente, apresentaram crescimento de todos os pontos esqueléticos de forma significativa $(1,2$ a $3,7 \mathrm{~mm})$; porém, quando comparados entre si, a quantidade de crescimento na região do côndilo, ramo e base da mandíbula não foi estatisticamente diferente. Quanto às alterações dentárias, ocorreu maior inclinação dos incisivos inferiores para vestibular $(1,86 \mathrm{~mm})$ nos pacientes menos maduros, e maior extrusão dos primeiros molares permanentes $(4,8 \mathrm{~mm})$ nos pacientes mais maduros.

Palavras-chave: Má oclusão de Angle Classe II. Ortopedia. Crescimento e desenvolvimento.

${ }^{1}$ Professor, Barretos University - UNIFEB

${ }^{2} \mathrm{PhD}$ in Orthodontics. Assistant Professor, Children's Clinic Department,

School of Dentistry of Araraquara - UNESP.

${ }^{3}$ Full Professor, Children's Clinic Department, School of Dentistry of Araraquara - UNESP.

${ }^{4} \mathrm{MSc}$ in Orthodontics, FOB-USP. Professor, Ribeirão Preto University UNAERP.

" The authors report no commercial, proprietary or financial interest in the products or companies described in this article.
How to cite this article: Santos-Pinto PR, Martins LP, Santos-Pinto A, Gandini Júnior LG, Raveli DB, Santos-Pinto CCM. Mandibular growth and dentoalveolar development in the treatment of Class II, division 1, malocclusion using Balters Bionator according to the skeletal maturation. Dental Press J Orthod. 2013 July-Aug;18(4):43-52.

Submitted: August 04, 2009 - Revised and accepted: December 29, 2010

Contact address: Prof. Paulo Roberto dos Santos-Pinto Orthodontic Center - Rua Américo Brasiliense, 1702 - Sala 5, CEP: 14015-050 - Ribeirão Preto/SP - Brazil

E-mail: dr-pauloroberto@hotmail.com 


\section{INTRODUCTION}

The treatment of Class II malocclusion with functional appliances, studied for decades in experimental studies in animals and humans, prove that this therapy is able to rearrange the growth and normal development of the face, ${ }^{26,28}$ with skeletal and dentoalveolar effects, important for the correction of malocclusion. ${ }^{12,21,23}$ Regarding mandible, studies with different methodologies have proven that functional therapy in patients with Class II malocclusion, can alter condylar growth and promote mandibular bone remodeling. ${ }^{26,28}$ However, the condylar growth is up to nowadays, a controversial and poorly defined fact. ${ }^{22}$

The importance of this study of Class II treatment with Balters bionator appliance lies in the use of $45^{\circ}$ lateral teleradiographs, to allow an evaluation without overlapping anatomical structures, ${ }^{16}$ by referential of metallic implants ${ }^{24}$ and the distribution of these patients by bone age, which makes the results more reliable.

There are studies already that used similar methodologies ${ }^{23}$ however, the clinician still has difficulty in defining the ideal stage to start intervention, because literature is often contradictory, with authors arguing that in young patients the mandibular length increase may occur with the use of these appliances, ${ }^{5,24}$ challenged by authors who claim that this form of treatment does not grow the mandible, because puberty is where the child has more growth earnings. ${ }^{22}$
The objective of this study is to evaluate the influence of bone maturation, in mandibular and dentoalveolar growth and development, natural and induced by treatment of Class II malocclusion, division 1, with Balters bionator.

\section{MATERIAL AND METHODS}

This study used radiographs of a sample composed by 23 Caucasian patients being 09 males and $14 \mathrm{fe}-$ males, with bone ages between 7-10 years, Angle's Class II malocclusion, division 1 , and mandibular deficiency. Oblique lateral radiographs, $45^{\circ}$ (oblique teleradiography), of right and left hemimandibles, and hand and wrist radiographs were taken by the same technician on the same day, using X-ray machine (Funk Orbital X15), Lanex screens and TMG film with the factors: $82 \mathrm{kVp}, 80 \mathrm{~mA}$ and 0.5 seconds exposure. These radiographs were collected prospectively in two stages with an interval of 1 year and archived in the Post-Graduation Course in Orthodontics, School of Dentistry - UNESP, in the city of Araraquara (SP).

Patients in the study were divided into 3 groups according to bone age obtained by the method of Eklöf and Ringertz using the program Radiocef Studio, Radiocef Studio version, based on measurements of 10 dimensions of the bones of the hand and wrist in radiographs images scanned. Control group (C),

Table 1 - Descriptive statistics of samples per treatment group.

\begin{tabular}{|c|c|c|c|c|c|}
\hline & & \multicolumn{3}{|c|}{ Values } & \multirow{2}{*}{ Mean \pm S.D. } \\
\hline & & $n$ & Minimum & Maximum & \\
\hline \multirow{5}{*}{$\begin{array}{l}\text { Control } \\
\text { group }\end{array}$} & Chronological age - start & 7 & 6.9 & 10.2 & $8.7 \pm 1.05$ \\
\hline & Chronological age - end & 7 & 7.9 & 11.2 & $9.7 \pm 1.07$ \\
\hline & Treatment time & 7 & 0.9 & 1 & $1 \pm 0.06$ \\
\hline & Skeletal maturity - start & 7 & 8.5 & 9.4 & $9 \pm 0.34$ \\
\hline & Skeletal maturity - end & 7 & 9.3 & 10.3 & $9.8 \pm 0.41$ \\
\hline \multirow{5}{*}{ Group 1} & Chronological age - start & 6 & 7.1 & 9.8 & $8.4 \pm 1.11$ \\
\hline & Chronological age - end & 6 & 7.9 & 10.7 & $9.4 \pm 1.16$ \\
\hline & Treatment time & 6 & 0.8 & 1.1 & $1 \pm 0.09$ \\
\hline & Skeletal maturity - start & 6 & 7 & 8.5 & $8 \pm 0.54$ \\
\hline & Skeletal maturity - end & 6 & 8.6 & 9.7 & $9.1 \pm 0.36$ \\
\hline \multirow{5}{*}{ Group 2} & Chronological age - start & 10 & 8.7 & 11.2 & $9.8 \pm 0.78$ \\
\hline & Chronological age - end & 10 & 9.8 & 12.2 & $10.8 \pm 0.78$ \\
\hline & Treatment time & 10 & 1 & 1.2 & $1.1 \pm 0.07$ \\
\hline & Skeletal maturity - start & 10 & 9.3 & 10.7 & $10 \pm 0.42$ \\
\hline & Skeletal maturity - end* & 9 & 9.9 & 11.5 & $10.6 \pm 0.57$ \\
\hline
\end{tabular}

* It was not reported the skeletal maturity of a Group 2 patient. 
with patients without treatment with 8.5 to 9.4 years of bone age and, treated Groups 1 and 2, with patients with initial bone age 7 to 8.5 years and 9.3 to 10.7 years, respectively (Table 1).

The appliance used in patients of treated groups was the bionator described by Balters, ${ }^{4}$ with acrylic deep extension of the lower arch seeking greater mucosal support in the lingual region and always made by the same professional. ${ }^{23}$

All patients received three tantalum metal implants, measuring $0.5 \mathrm{~mm}$ in diameter and $1.5 \mathrm{~mm}$ length, positioned on the mandible cortical surface as the method developed by Björk. ${ }^{8}$ The first positioned at the center of the symphysis, between the roots of the incisors and the other two positioned in the posterior region, between the roots of the lower first permanent molars, right and left.

Aiming to evaluate mandibular growth and tooth development, natural and induced by orthopedic treatment with Balters bionator, it was established 16 cephalometric points marked in visualized right and left oblique radiographs of the mandible: Condylar points (co, coa, cop, cla, and clp) points in the ramus region (ramp, rams, rma and rmi) and lower border (gop, go, goa, me, bora, borm and borp) (Table 1).

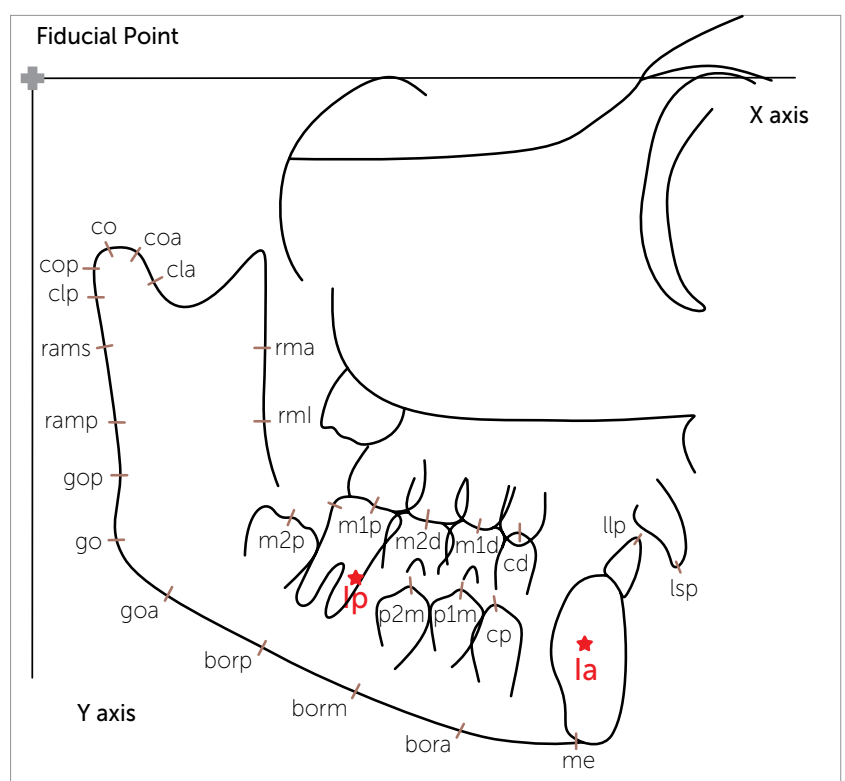

Figure 1 - X axis represented by the horizontal line formed by the orbital plane determined on the initial radiograph $\left(T_{1}\right)$, transferred to the subsequent radiographs through the superposition of metallic implants. Y axis determined by a vertical line passing through the fiducial point located at the posterior end of the orbital plane with points on the mandibular body: Condylar (co, coa, cop, cla, and clp); mandibular ramus points (ramp, rams, rma and rmi); lower border (gop, go, goa, me, bora, borm, and borp); and dental points (isp, iip, $c p, m 1 p, m 2 p, p 1 m, p 2 m, m 1 d, m 2 d$ and $c d)$.
The points marked on the permanent teeth were icp, iip, cp, m1p, m2p, p1m and $\mathrm{p} 2 \mathrm{~m}$ and on deciduous teeth: $\mathrm{cd}, \mathrm{m} 1 \mathrm{~d}$ and $\mathrm{m} 2 \mathrm{~d}$, totaling 10 dental points, and 2 reference points of implant (Fig 1, Table 2).

For analysis of the displacements of cephalometric landmarks it was used a Cartesian coordinate system.

The $\mathrm{X}$ axis is represented by the horizontal line formed by the orbital plane determined in the initial radiographic $\left(\mathrm{T}_{1}\right)$ and transferred to subsequent radiographs through the superimposition of the images of metallic implants located at the anterior and posterior mandible (Ip and Ia). The Y axis is represented by the vertical line perpendicular to the orbital plane passing through a fiducial point located at the rear end of the orbit plane in a rearmost position to skeletal and dental structures of cephalometric tracing. The anteroposterior position of each cephalometric point was obtained by linear distance from point referred to the Y axis, parallel to the axis X. Similarly, the vertical position of each cephalometric point was obtained by linear distance from the point to the $\mathrm{X}$ axis parallel to the $\mathrm{Y}$ axis (Fig 1).

The horizontal displacement for each point was calculated as the difference between the linear horizontal distance of the points at two different instants $\left(\mathrm{I}_{2}-\mathrm{I}_{1}\right)$ where $\mathrm{I}_{1}$ represents the beginning of orthopedic treatment (treated group) or beginning of the observation period (control) and $\mathrm{I}_{2}$, the displacement after 1 year of orthopedic therapy (treated group) or end of the observation period (Control group). The total displacement of each point was obtained using the rule of the right triangle (total displacement equal to the square root of the sum of squared horizontal displacement and vertical displacement squared).

This study was approved on May 4, 2009 by the research ethics committee of the Faculty of Dentistry of Araraquara under protocol 39/06, which is in accordance with resolution 196/96 of the National Health Council/MS.

\section{STATISTICAL ANALYSES}

The predetermined points in the radiographs were digitized twice by the same calibrated operator every 15 days, using the IBM compatible personal computer with the program Dentofacial Planner Plus version 2.02, on Numonics Accugrid digitizing tablet. Data were taken to the Excel Program in IBM micro- 
Table 2 - Skeletal and dental cephalometric measurements:

\begin{tabular}{|c|c|c|}
\hline Point & Name & Definition \\
\hline Condylion & $\mathrm{co}$ & Most superior point of the mandibular condyle \\
\hline Anterior condylion & coa & Most anterior point of the mandibular condyle \\
\hline Posterior condylion & cop & Most posterior point of the mandibular condyle \\
\hline Anterior condylar neck & cla & Most anterior point of the mandibular condyle neck \\
\hline Posterior condylar neck & clp & Most posterior point of the condylar neck \\
\hline Posterior superior ramus & rams & Most posterior and superior point of the ramus of the mandible \\
\hline Posterior median ramus & ramp & Most posterior and median point of the ramus of the mandible \\
\hline Anterior superior ramus & rma & Located at the anterior and superior surface of the ramus of the mandible \\
\hline Anterior median ramus & rmi & Located at the anterior and median surface of the ramus of the mandible \\
\hline Superior gonion & gop & Most upper (superior) and posterior point of the gonial angle \\
\hline Gonion & go & Most lower (inferior) and posterior point of the gonial angle \\
\hline Antegonial notch & goa & Located at the antegonial notch region \\
\hline Menton & me & Located at the base of the mandible. In the intersection with mandibular symphysis \\
\hline $\begin{array}{l}\text { The landmarks of the posterior, median and } \\
\text { anterior base of the mandible }\end{array}$ & $\begin{array}{l}\text { borp, borm } \\
\text { and bora }\end{array}$ & $\begin{array}{l}\text { Landmarks determined, respectively, from goa, by dividing the segment goa me in three } \\
\text { equidistant points }\end{array}$ \\
\hline Posterior implant & Ip & Mandibular landmark which the implant is Located at the posterior surface of the mandibular body \\
\hline Anterior implant & la & Mandibular landmark which the implant is Located at the anterior of the mandibular body \\
\hline Upper permanent incisor & isp & Located at the incisal edge of the upper incisor \\
\hline Lower permanent incisor & iip & Located at the incisal edge of the lower incisor \\
\hline Lower permanent canine & $\mathrm{cp}$ & Located at the incisal edge of the lower canine \\
\hline Lower deciduous canine & $c d$ & Located at the incisal edge of the lower deciduous canine \\
\hline Mandibular first premolar & $\mathrm{p} 1 \mathrm{~m}$ & Located at the incisal edge of the mandibular first premolar \\
\hline Mandibular second premolar & $\mathrm{p} 2 \mathrm{~m}$ & Located at the incisal edge of the mandibular second premolar \\
\hline Deciduous mandibular first molar & m1d & Located at the incisal edge of the deciduous mandibular first molar \\
\hline Deciduous mandibular second molar & $\mathrm{m} 2 \mathrm{~d}$ & Located at the incisal edge of the deciduous mandibular second molar \\
\hline Permanent mandibular first molar & m1p & Located at the middle portion of the occlusal surface of the permanent mandibular first molar \\
\hline Permanent mandibular second molar & $m 2 p$ & Located at the middle portion of the occlusal surface of the permanent mandibular second molar \\
\hline
\end{tabular}

computer and statistically analyzed using SPSS. This procedure was performed to evaluate the error of the method in the scanning process. It was applied Intraclass Correlation Coefficient (ICC) which showed variations from 0.893 to 0.996 , with the smallest corresponding to the point $\mathrm{m} 1 \mathrm{~d}(\mathrm{v})$ and the highest to points oj, $\operatorname{cop}(\mathrm{v}) \operatorname{coa}(\mathrm{v})$ and $\mathrm{rmd}$, demonstrating that the error method was not significant.

For comparison between groups, the data were annualized in order to balance the small difference in time for observation or treatment from 0.8 to 1.2 years (Table 1 ).

From each patient, at each study point, it was obtained two oblique teleradiographs one on the right side and another on the left side. The study of correlation of the displacements of the predetermined points on both sides employing the Pearson correlation coefficient showed that for $77 \%$ of them the correlation is zero or very weak and $16 \%$ of the correlation is moderate showing that a promoted correction by the device or natural growth is not necessarily symmetric. Based on these results it was chosen to work with the measurements of both sides as independent measures.

For statistical analysis of the displacement of each point, it was employed Student's t test for the mean of a population. To assess whether the means of each measure in the three groups were equal, it was used analysis of variance with a criterion of classification (ANOVA) when the homogeneity test of variances was not significant, otherwise the statistical analysis was performed by the Brown-Forsythe test. It was conducted tests of multiple comparison of means for variables that showed statistically significant results in testing the hypothesis of equality of means. The significance level for all statistical tests was $95 \%(\mathrm{p}<0.05)$. 
Table 3 - Mean and standard deviation of mandibular growth, tooth eruption (total, horizontal and vertical) and significance of the Student's t test of the hypothesis that the mean is equal to zero - Control Group.

\begin{tabular}{|c|c|c|c|c|c|}
\hline & Point & $n$ & $\begin{array}{c}\text { Total } \\
\text { Mean } \pm \text { SD }\end{array}$ & $\begin{array}{l}\text { Horizontal } \\
\text { Mean } \pm \text { SD }\end{array}$ & $\begin{array}{c}\text { Vertical } \\
\text { Mean } \pm \text { SD }\end{array}$ \\
\hline \multirow{16}{*}{ 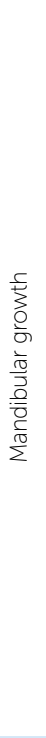 } & me & 14 & $1.20 * * \pm 0.97$ & $-0.35^{n s} \pm 1.12$ & $0.74^{\star *} \pm 0.72$ \\
\hline & bora & 14 & $1.37^{\star \star} \pm 1.12$ & $-0.69^{\text {ns }} \pm 1.52$ & $0.20^{\text {ns }} \pm 0.63$ \\
\hline & borm & 14 & $1.73^{\star \star} \pm 1.42$ & $-0.55^{\mathrm{ns}} \pm 1.97$ & $0.11^{\text {ns }} \pm 1.01$ \\
\hline & borp & 14 & $2.14^{* *} \pm 1.40$ & $-0.87^{n s} \pm 2.13$ & $0.02^{n s} \pm 1.24$ \\
\hline & goa & 14 & $2.07^{* *} \pm 1.01$ & $-0.71^{n s} \pm 1.79$ & $-0.20^{n s} \pm 1.37$ \\
\hline & go & 14 & $1.90^{\star *} \pm 1.29$ & $-1.03^{* \star} \pm 1.00$ & $-0.86^{n s} \pm 1.61$ \\
\hline & gop & 14 & $2.07^{\star *} \pm 1.25$ & $-0.89^{* \star} \pm 0.80$ & $-1.21^{*} \pm 1.77$ \\
\hline & ramp & 14 & $2.28^{\star *} \pm 1.11$ & $-0.69^{*} \pm 0.90$ & $-1.40^{\star} \pm 1.84$ \\
\hline & rams & 14 & $2.10^{* *} \pm 0.95$ & $-0.78^{\star *} \pm 0.85$ & $-1.42^{\star \star} \pm 1.44$ \\
\hline & clp & 14 & $2.27^{\star \star} \pm 1.41$ & $-0.52^{\star} \pm 0.83$ & $-1.76^{\star \star} \pm 1.79$ \\
\hline & cop & 14 & $2.18^{\star *} \pm 1.57$ & $-0.68^{\star} \pm 0.97$ & $-1.51^{*} \pm 1.92$ \\
\hline & $\mathrm{CO}$ & 14 & $2.29 * * \pm 1.65$ & $-0.69 * \pm 0.93$ & $-1.68^{\star *} \pm 1.99$ \\
\hline & coa & 14 & $2.35^{\star *} \pm 1.71$ & $-0.40^{n s} \pm 1.02$ & $-1.83^{\star *} \pm 2.01$ \\
\hline & cla & 14 & $2.40^{* *} \pm 1.52$ & $-0.45^{\star} \pm 0.76$ & $-2.02^{* \star} \pm 1.82$ \\
\hline & rma & 14 & $1.83^{\star \star} \pm 1.10$ & $-0.55^{\star} \pm 0.82$ & $-1.11^{\star} \pm 1.58$ \\
\hline & rmi & 14 & $2.94^{\star \star} \pm 2.23$ & $-0.30^{\text {ns }} \pm 3.20$ & $-0.80^{n s} \pm 1.82$ \\
\hline \multirow{8}{*}{ 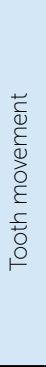 } & $m 2 p$ & 14 & $2.18^{\star \star} \pm 1.18$ & $1.48^{\star \star} \pm 1.31$ & $-1.16^{\star \star} \pm 1.00$ \\
\hline & m1p & 14 & $2.19^{* *} \pm 1.14$ & $0.49^{\text {ns }} \pm 1.07$ & $-1.85^{\star *} \pm 1.16$ \\
\hline & m2d & 12 & $1.54^{\star \star} \pm 0.58$ & $0.48^{\text {ns }} \pm 1.03$ & $-0.59^{n s} \pm 1.11$ \\
\hline & $\mathrm{p} 2 \mathrm{~m}$ & 14 & $2.79 * * \pm 2.01$ & $1.31^{\star \star} \pm 1.24$ & $-2.36^{\star \star} \pm 1.75$ \\
\hline & m1d & 9 & $1.13^{\star \star} \pm 0.88$ & $0.08^{\text {ns }} \pm 1.23$ & $-0.46^{n s} \pm 0.68$ \\
\hline & p1m & 14 & $2.67^{\star \star} \pm 2.15$ & $1.38^{\star} \pm 2.28$ & $-1.84^{\star \star} \pm 1.16$ \\
\hline & $c p$ & 13 & $4.96^{\star \star} \pm 2.12$ & $1.00^{*} \pm 1.36$ & $-4.72^{\star \star} \pm 2.01$ \\
\hline & iip & 14 & $1.52^{\star \star} \pm 0.80$ & $0.72^{\star *} \pm 0.84$ & $0.58^{\text {ns }} \pm 1.22$ \\
\hline
\end{tabular}

* - the hypothesis that the mean is zero is rejected at a significance level of 0.05 . ** - the hypothesis that the mean is zero is rejected at a significance level of 0.01 ns - the hypothesis that the mean is zero is not rejected.

\section{RESULTS}

According to the analyzed sample and the measurements it is possible to say that, accompanied by one year without treatment, natural growth occurred promoting back horizontal changes at goa and go points and back and down at points gop, ramp, rams, clp, cop, co, coa, cla and rma and, only down at point me, with statistical significance (Table 3).

The results of the displacement of dental points of this Control group were significant for the overall tooth displacement. Horizontally it occurred labial migration of incisors, the $\mathrm{m} 2 \mathrm{p}$ points, $\mathrm{p} 2 \mathrm{~m}, \mathrm{p} 1 \mathrm{~m}$ and $\mathrm{cp}$ points moved to mesial and occlusal and $\mathrm{m} 1 \mathrm{p}$ shifted toward occlusal significantly. The remaining evaluated teeth showed no significant changes in this group.
Table 4 - Mean and standard deviation of mandibular growth, tooth eruption (total, horizontal and vertical) and significance of the Student's t test of the hypothesis that the mean is equal to zero - Group 1

\begin{tabular}{|c|c|c|c|c|c|}
\hline & Point & $n$ & $\begin{array}{c}\text { Total } \\
\text { Mean } \pm \text { SD }\end{array}$ & $\begin{array}{l}\text { Horizontal } \\
\text { Mean } \pm \text { SD }\end{array}$ & $\begin{array}{l}\text { Vertical } \\
\text { Mean } \pm \text { SD }\end{array}$ \\
\hline \multirow{16}{*}{$\begin{array}{l}\frac{5}{1} \\
3 \\
0 \\
0 \\
\frac{1}{\pi} \\
\frac{1}{5} \\
\overline{0} \\
\frac{1}{0} \\
\sum\end{array}$} & me & 11 & $1.71^{* *} \pm 0.73$ & $0.58^{s n} \pm 1.31$ & $0.69^{s n} \pm 1.07$ \\
\hline & bora & 11 & $1.39^{* \star} \pm 1.03$ & $0.55^{5 n} \pm 1.53$ & $0.39^{s n} \pm 0.60$ \\
\hline & borm & 11 & $1.64^{\star *} \pm 1.79$ & $0.36^{\text {sn }} \pm 2.06$ & $0.19^{s n} \pm 1.32$ \\
\hline & borp & 11 & $1.67^{\star \star} \pm 1.33$ & $-0.55^{5 n} \pm 1.65$ & $-0.48^{\mathrm{sn}} \pm 1.24$ \\
\hline & goa & 11 & $3.30^{* \star} \pm 2.68$ & $-1.69^{\text {sn }} \pm 3.35$ & $-0.78^{\mathrm{sn}} \pm 2.03$ \\
\hline & go & 11 & $2.31^{\star \star} \pm 1.45$ & $-1.30 * * \pm 0.74$ & $-1.32^{* *} \pm 1.92$ \\
\hline & gop & 11 & $2.63^{\star *} \pm 1.40$ & $-1.31^{\star \star} \pm 0.66$ & $-1.79 * * \pm 1.93$ \\
\hline & ramp & 11 & $2.65^{\star \star} \pm 1.86$ & $-0.95^{\star *} \pm 1.03$ & $-2.01^{\star \star} \pm 2.16$ \\
\hline & rams & 11 & $2.93^{\star *} \pm 1.77$ & $-0.88^{\star \star} \pm 1.07$ & $-2.27^{\star \star} \pm 2.22$ \\
\hline & clp & 11 & $2.64^{* *} \pm 2.09$ & $-0.73^{\star \star} \pm 0.81$ & $-2.22^{\star *} \pm 2.32$ \\
\hline & cop & 11 & $2.76^{* *} \pm 1.67$ & $-0.56^{\mathrm{sn}} \pm 1.01$ & $-2.39 * * \pm 1.88$ \\
\hline & $\mathrm{CO}$ & 11 & $2.75^{* *} \pm 1.90$ & $-0.58^{s n} \pm 1.13$ & $-2.27^{\star *} \pm 2.16$ \\
\hline & $\mathrm{coa}$ & 11 & $2.94^{\star *} \pm 1.86$ & $-0.45^{\mathrm{sn}} \pm 1.18$ & $-2.60^{* *} \pm 1.98$ \\
\hline & cla & 11 & $2.65^{\star *} \pm 2.11$ & $-0.27^{5 n} \pm 0.60$ & $-2.34^{\star *} \pm 2.39$ \\
\hline & rma & 11 & $2.25^{\star *} \pm 1.60$ & $-0.38^{\mathrm{sn}} \pm 1.48$ & $-1.49^{* *} \pm 1.84$ \\
\hline & rmi & 11 & $2.32^{\star *} \pm 1.26$ & $-0.75^{\mathrm{sn}} \pm 1.37$ & $-1.59^{* *} \pm 1.50$ \\
\hline \multirow{8}{*}{ 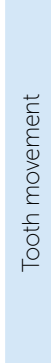 } & $m 2 p$ & 11 & $2.55^{\star \star} \pm 1.34$ & $2.14^{\star \star} \pm 1.32$ & $-0.92^{\star \star} \pm 1.12$ \\
\hline & m1p & 11 & $3.11^{\star \star} \pm 1.93$ & $0.84^{\star *} \pm 0.74$ & $-2.66^{\star \star} \pm 2.28$ \\
\hline & m2d & 8 & $1.30 * \star \pm 0.74$ & $0.61^{* *} \pm 0.67$ & $-0.56^{n s} \pm 1.13$ \\
\hline & $\mathrm{p} 2 \mathrm{~m}$ & 11 & $2.73^{* \star} \pm 1.92$ & $1.45^{\star \star} \pm 1.23$ & $-1.95^{\star \star} \pm 1.97$ \\
\hline & m1d & 7 & $1.57^{\star *} \pm 1.11$ & $0.79^{s n} \pm 1.56$ & $-0.45^{\text {ns }} \pm 0.83$ \\
\hline & $\mathrm{p} 1 \mathrm{~m}$ & 11 & $3.21^{\star *} \pm 2.22$ & $1.23^{\star \star} \pm 1.25$ & $-2.66^{* *} \pm 2.28$ \\
\hline & $\mathrm{cp}$ & 11 & $4.14^{\star *} \pm 2.00$ & $0.21^{\mathrm{sn}} \pm 1.19$ & $-3.90^{* *} \pm 2.15$ \\
\hline & iip & 11 & $2.70^{\star \star} \pm 1.31$ & $1.86^{\star \star} \pm 1.09$ & $1.71^{\star \star} \pm 1.26$ \\
\hline
\end{tabular}

* - the hypothesis that the mean is zero is rejected at a significance level of 0.05 .

** - the hypothesis that the mean is zero is rejected at a significance level of 0.01 . ns - the hypothesis that the mean is zero is not rejected.

The data from Group 1 (Table 4), of patients with lower bone age or less mature, showed significant total displacement of all studied points, both for measures of skeletal origin as tooth measures.

The total tooth movements were all significant, with mesial movement of all teeth, except the first deciduous molars and canines, and significant extrusion of permanent teeth $(\mathrm{m} 1 \mathrm{p}, \mathrm{m} 2 \mathrm{p}, \mathrm{p} 1 \mathrm{~m}, \mathrm{p} 2 \mathrm{~m}, \mathrm{cp})$.

Significant changes occurred in both horizontal and vertical at goa, go, gop, ramp, rams, clp, cop, co, coa, cla, rmi points, only horizontally at borp point, and vertically at me and rma points.

The dental changes in both horizontal and vertical occurred with significant mesial movement and extrusion of points $\mathrm{m} 2 \mathrm{p}, \mathrm{p} 2 \mathrm{~m}$, and $\mathrm{cp}$, only extrusion at $\mathrm{m} 1 \mathrm{p}, \mathrm{p} 1 \mathrm{~m}$ points. 
Table 5 - Means and standard deviation of the mandibular growth and total dental eruption, horizontal and vertical, and t test significance of the hypothesis that the mean is equal to zero - Group 3.

\begin{tabular}{|c|c|c|c|c|c|}
\hline & Point & $n$ & $\begin{array}{c}\text { Total } \\
\text { Mean } \pm \text { SD }\end{array}$ & $\begin{array}{l}\text { Horizontal } \\
\text { Mean } \pm \text { SD }\end{array}$ & $\begin{array}{c}\text { Vertical } \\
\text { Mean } \pm \text { SD }\end{array}$ \\
\hline \multirow{16}{*}{ 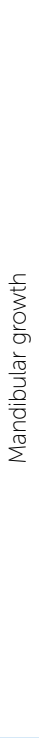 } & me & 20 & $1.45^{* \star} \pm 0.75$ & $-0.17^{n s} \pm 1.19$ & $0.50 * \pm 1.04$ \\
\hline & bora & 20 & $1.95^{\star \star} \pm 1.16$ & $-0.73^{n s} \pm 1.95$ & $0.29^{n s} \pm 0.94$ \\
\hline & borm & 20 & $1.77^{\star *} \pm 1.47$ & $-0.89^{n s} \pm 1.93$ & $0.01^{\mathrm{ns}} \pm 0.94$ \\
\hline & borp & 20 & $2.18^{* *} \pm 2.07$ & $-1.31^{*} \pm 2.35$ & $-0.48^{\text {ns }} \pm 1.30$ \\
\hline & goa & 20 & $2.68^{\star \star} \pm 1.87$ & $-1.61^{\star \star} \pm 2.23$ & $-1.13^{\star \star} \pm 1.41$ \\
\hline & go & 20 & $2.42^{* *} \pm 1.48$ & $-1.26^{\star *} \pm 1.68$ & $-1.27^{\star *} \pm 1.47$ \\
\hline & gop & 20 & $2.58^{\star \star} \pm 1.69$ & $-1.24^{\star *} \pm 1.52$ & $-1.48^{\star *} \pm 1.91$ \\
\hline & ramp & 20 & $2.77^{\star \star} \pm 1.64$ & $-0.94^{\star \star} \pm 1.18$ & $-1.53^{\star} \pm 2.45$ \\
\hline & rams & 20 & $3.05^{* *} \pm 2.26$ & $-0.83^{\star *} \pm 1.07$ & $-2.22^{* *} \pm 2.80$ \\
\hline & clp & 20 & $3.62^{\star *} \pm 3.12$ & $-1.11^{\star *} \pm 1.51$ & $-2.75^{\star \star} \pm 3.47$ \\
\hline & cop & 20 & $3.53^{\star *} \pm 3.09$ & $-1.04^{\star} \pm 1.70$ & $-2.70 * * \pm 3.31$ \\
\hline & $\mathrm{CO}$ & 20 & $3.57^{\star \star} \pm 3.13$ & $-1.23^{\star \star} \pm 1.89$ & $-2.68^{\star \star} \pm 3.24$ \\
\hline & coa & 20 & $3.70^{* *} \pm 3.27$ & $-1.28^{* *} \pm 1.70$ & $-2.77^{* *} \pm 3.52$ \\
\hline & cla & 20 & $3.54^{* *} \pm 3.02$ & $-1.08^{* *} \pm 1.54$ & $-2.62^{\star \star} \pm 3.39$ \\
\hline & rma & 20 & $3.01^{* \star} \pm 1.79$ & $-0.74^{\text {ns }} \pm 1.61$ & $-1.67^{\star \star} \pm 2.58$ \\
\hline & $\mathrm{rmi}$ & 20 & $3.05^{\star \star} \pm 1.64$ & $-1.01^{\star} \pm 2.15$ & $-1.55^{\star \star} \pm 2.07$ \\
\hline \multirow{8}{*}{ 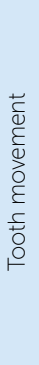 } & $m 2 p$ & 20 & $3.14^{\star *} \pm 1.17$ & $1.72^{\star \star} \pm 0.95$ & $-2.37^{\star \star} \pm 1.35$ \\
\hline & m1p & 20 & $4.83^{\star *} \pm 2.52$ & $0.40^{\text {ns }} \pm 0.94$ & $-4.64^{* *} \pm 2.68$ \\
\hline & m2d & 18 & $1.33^{\star *} \pm 0.73$ & $0.14^{\text {ns }} \pm 1.18$ & $-0.37^{n s} \pm 0.93$ \\
\hline & $\mathrm{p} 2 \mathrm{~m}$ & 20 & $2.21^{\star \star} \pm 1.81$ & $0.94^{\star *} \pm 1.42$ & $-1.50 * * \pm 1.76$ \\
\hline & m1d & 5 & $1.21^{*} \pm 0.87$ & $0.95^{\text {ns }} \pm 1.10$ & $-0.15^{n s} \pm 0.48$ \\
\hline & p1m & 20 & $5.35^{\star *} \pm 2.40$ & $0.68^{\text {ns }} \pm 2.34$ & $-4.64^{\star *} \pm 2.68$ \\
\hline & $\mathrm{cp}$ & 19 & $4.29^{\star *} \pm 2.22$ & $1.08^{\star \star} \pm 1.09$ & $-3.97^{\star \star} \pm 2.31$ \\
\hline & iip & 20 & $1.90^{* \star} \pm 1.12$ & $0.40^{\text {ns }} \pm 1.55$ & $0.59^{\text {ns }} \pm 1.46$ \\
\hline
\end{tabular}

* - the hypothesis that the mean is zero is rejected at a significance level of 0.05 . ** - the hypothesis that the mean is zero is rejected at a significance level of 0.01 . ns - the hypothesis that the mean is zero is not rejected.

To evaluate whether the average of each measure in the three groups were equal it was used analysis of variance with one classification criterion (ANOVA) when the test for homogeneity of variance was not significant, otherwise the comparison of means was performed by Brown-Forsythe test. The results are shown in Tables 6 and 7, and in Table 8 the results of the multiple comparisons of means of variables that showed statistically significant results in test for difference of means.

The data in Table 6 show that, except for the measure iip, there are no statistical differences between the means of the horizontal measures of mandibular growth and tooth migration. The results of the multiple comparisons of means (Table 8) show that the iip mean from Group 1 differs from means of Control group and Group 2. For measures of vertical growth, the results indicate that there is significant difference between the group's means only for some measures of tooth movement, $\mathrm{m} 2 \mathrm{p}, \mathrm{m} 1 \mathrm{p}$ and $\mathrm{p} 1 \mathrm{~m}$. Regarding to $\mathrm{p} 1 \mathrm{~m}$ it was also observed no significant difference between the variances of the three groups. The results of multiple comparisons of means show that, for the three measures cited above, the vertical growth in Group 2 was higher and significantly different from the other two groups.

\section{DISCUSSION}

This work was carried out at $45^{\circ}$ oblique teleradiographs of patients who had metal implants inserted in the mandible, used as stable references, what allowed a more reliable evaluation of the results. This feature eliminates variables like the magnification of radiographic images ${ }^{3}$ and incorrect positioning of the patients head in cephalostat. The images of implants as suggested by Bjork ${ }^{8}$ were marked on the initial teleradiograph and transferred to the subsequent, providing an assessment of the real displacement of the points in evaluated time (for all groups), which otherwise would not be possible. ${ }^{23}$

Identifying whether the orthopedic device only changes the direction of condylar growth or the rate and amount of this growth has been the purpose of many authors. Bjork and Skieller ${ }^{9}$ cite the importance, in longitudinal studies, the condylar growth in mandible length increase, being the growth direction of the condyle extremely variable and difficult to predict. The real role of the condyle in the mandibular growth is controversial in craniofacial growth studies. The cartilage of the condyle has a capacity of compensatory growth, generating enough growth to allow adaptation of the mandible to the skull base by articular fossa (mandibular fossa) and to maxillary complex.

In the Control group of our study, the growth of the condyle was significant in all its references, anterior and posterior condylar neck (cla and clp), posterior and superior portion (cop and co), up and back. The anterior condylar region (coa) was an exception and showed no backward growth.

With the use of the appliance in younger children (Group 1) the condyle showed no significant 
Table 6 - Results of tests for homogeneity of variance (Levene's test) and to test the hypothesis that the mean of the 3 groups are equal (ANOVA or Brown Forsythe test) - points with vertical and horizontal movements.

\begin{tabular}{|c|c|c|c|c|c|c|c|c|c|c|c|c|}
\hline \multirow{3}{*}{ Point } & \multicolumn{6}{|c|}{ Horizontal movement } & \multicolumn{6}{|c|}{ Vertical movement } \\
\hline & \multicolumn{3}{|c|}{ Levene's test } & \multicolumn{3}{|c|}{ ANOVA } & \multicolumn{3}{|c|}{ Levene's test } & \multicolumn{3}{|c|}{ ANOVA } \\
\hline & $F$ & gl1 / gl2 & Sig. & $F$ & $\mathrm{gl1} / \mathrm{gl2}$ & Sig. & $F$ & $\mathrm{gl} / \mathrm{g} / 2$ & Sig. & $F$ & $\mathrm{gl1} / \mathrm{gl2}$ & Sig. \\
\hline me & 0.24 & $2 / 42$ & 0.789 & 2.04 & $2 / 42$ & 0.142 & 0.47 & $2 / 42$ & 0.629 & 0.30 & $2 / 42$ & 0.742 \\
\hline bora & 1.29 & $2 / 42$ & 0.287 & 2.22 & $2 / 42$ & 0.121 & 1.10 & $2 / 42$ & 0.341 & 0.19 & $2 / 42$ & 0.824 \\
\hline borm & 0.02 & $2 / 42$ & 0.981 & 1.43 & $2 / 42$ & 0.252 & 0.02 & $2 / 42$ & 0.981 & 0.11 & $2 / 42$ & 0.899 \\
\hline borp & 0.73 & $2 / 42$ & 0.488 & 0.48 & $2 / 42$ & 0.619 & 0.10 & $2 / 42$ & 0.902 & 0.76 & $2 / 42$ & 0.476 \\
\hline goa & 1.90 & $2 / 42$ & 0.162 & 0.71 & $2 / 42$ & 0.496 & 0.62 & $2 / 42$ & 0.543 & 1.45 & $2 / 42$ & 0.246 \\
\hline go & 2.02 & $2 / 42$ & 0.146 & 0.17 & $2 / 42$ & 0.845 & 0.22 & $2 / 42$ & 0.807 & 0.33 & $2 / 42$ & 0.719 \\
\hline gop & 2.55 & $2 / 42$ & 0.090 & 0.51 & $2 / 42$ & 0.607 & 0.01 & $2 / 42$ & 0.989 & 0.29 & $2 / 42$ & 0.746 \\
\hline ramp & 0.40 & $2 / 42$ & 0.674 & 0.27 & $2 / 42$ & 0.765 & 0.75 & $2 / 42$ & 0.481 & 0.25 & $2 / 42$ & 0.778 \\
\hline rams & 0.03 & $2 / 42$ & 0.970 & 0.03 & $2 / 42$ & 0.971 & 1.77 & $2 / 42$ & 0.183 & 0.60 & $2 / 42$ & 0.555 \\
\hline clp & 1.72 & $2 / 42$ & 0.192 & 1.06 & $2 / 42$ & 0.357 & 3.02 & $2 / 42$ & 0.060 & 0.52 & $2 / 42$ & 0.596 \\
\hline cop & 1.55 & $2 / 42$ & 0.225 & 0.53 & $2 / 42$ & 0.592 & 2.22 & $2 / 42$ & 0.121 & 0.85 & $2 / 42$ & 0.436 \\
\hline $\mathrm{CO}$ & 2.27 & $2 / 42$ & 0.116 & 0.91 & $2 / 42$ & 0.410 & 1.48 & $2 / 42$ & 0.239 & 0.58 & $2 / 42$ & 0.566 \\
\hline coa & 1.05 & $2 / 42$ & 0.359 & 2.09 & $2 / 42$ & 0.137 & 2.03 & $2 / 42$ & 0.144 & 0.50 & $2 / 42$ & 0.612 \\
\hline cla & 2.98 & $2 / 42$ & 0.062 & 2.20 & $2 / 42$ & 0.123 & 2.17 & $2 / 42$ & 0.127 & 0.20 & $2 / 42$ & 0.823 \\
\hline rma & 2.75 & $2 / 42$ & 0.076 & 0.25 & $2 / 42$ & 0.782 & 2.53 & $2 / 42$ & 0.091 & 0.28 & $2 / 42$ & 0.754 \\
\hline rmi & 1.15 & $2 / 42$ & 0.325 & 0.36 & $2 / 42$ & 0.700 & 0.93 & $2 / 42$ & 0.402 & 0.81 & $2 / 42$ & 0.453 \\
\hline $\mathrm{m} 2 \mathrm{p}$ & 1.18 & $2 / 42$ & 0.317 & 1.01 & $2 / 42$ & 0.375 & 0.61 & $2 / 42$ & 0.550 & 6.82 & $2 / 42$ & 0.003 \\
\hline m1p & 1.08 & $2 / 42$ & 0.350 & 0.81 & $2 / 42$ & 0.452 & 5.63 & $2 / 42$ & 0.007 & $7.87^{(1)}$ & $2 / 32$ & 0.002 \\
\hline $\mathrm{m} 2 \mathrm{~d}$ & 0.61 & $2 / 35$ & 0.550 & 0.69 & $2 / 35$ & 0.508 & 0.58 & $2 / 35$ & 0.563 & 0.20 & $2 / 35$ & 0.822 \\
\hline $\mathrm{p} 2 \mathrm{~m}$ & 0.22 & $2 / 42$ & 0.803 & 0.60 & $2 / 42$ & 0.551 & 0.01 & $2 / 42$ & 0.988 & 0.96 & $2 / 42$ & 0.392 \\
\hline m1d & 1.45 & $2 / 18$ & 0.261 & 0.91 & $2 / 18$ & 0.421 & 0.46 & $2 / 18$ & 0.639 & 0.37 & $2 / 18$ & 0.699 \\
\hline p1m & 0.24 & $2 / 42$ & 0.787 & 0.52 & $2 / 42$ & 0.598 & 5.57 & $2 / 42$ & 0.007 & $7.93^{(1)}$ & $2 / 32$ & 0.002 \\
\hline$c p$ & 0.06 & $2 / 40$ & 0.938 & 2.00 & $2 / 40$ & 0.149 & 0.48 & $2 / 40$ & 0.620 & 0.58 & $2 / 40$ & 0.563 \\
\hline iip & 1.50 & $2 / 40$ & 0.235 & 4.19 & $2 / 40$ & 0.022 & 0.20 & $2 / 40$ & 0.819 & 2.47 & $2 / 40$ & 0.097 \\
\hline
\end{tabular}

(1) The analysis of variance (ANOVA) was replaced by Brown and Forsythe statistical due to the heterogeneity of variances.

back growth and vertical growth similar to the Control group. In Group 2, with mature children, the condyle showed significant backwards and upwards growth, showing a modification of condylar growth more to posterior and superior as found by Araújo. ${ }^{3}$ This pattern of condylar growth did not differ from that presented by the children in the Control group, but there was greater vertical growth in both treated groups (1 and 2) and horizontal in Group 2 being discordant from results of Bjork $^{8}$ who suggests that backward growth from treatment might have been statistically significant compared to the Control group and Huttgren et al ${ }^{15}$ who reported that activators caused a redirection of the condyle in posterior position. These results are consistent with Monini, ${ }^{25}$ who found stability in the direction of condylar growth.

Our study showed that there were significant individual changes, but the comparison between groups, changes in relation to the condyle were not significant, allowing us to reaffirm the hypothesis of several authors ${ }^{3,20}$ who accepted the redirection of mandibular growth, however, nothing beyond the natural growth potential.

Regarding the mandibular ramus, it was found in the Control group a slip of the ramus to posterior represented by resorption of the anterior ramus (backward and upward) and apposition on the backward posterior. These data were observed both in the upper (rams and rma) and middle ramus (ramp and rmi).

The treated Groups 1 and 2 exhibited a displacement onto the upper anterior ramus and upward and backward in the lower ramus, similar to the Control group. These results are consistent with the process of ramus displacement relative to the mandibular body which occurs naturally during facial skeleton growth and development described by $\mathrm{Gu}$ and McNamara. ${ }^{14}$ 
Table 7 - Results of tests for homogeneity of variance (Levene's test) and to test the hypothesis that the mean of the 3 groups are equal (ANOVA or Brown Forsythe test) - landmarks with total movements.

\begin{tabular}{|c|c|c|c|c|c|c|}
\hline \multirow{3}{*}{ Point } & \multicolumn{6}{|c|}{ Total movement } \\
\hline & \multicolumn{3}{|c|}{ Levene's test } & \multicolumn{3}{|c|}{ ANOVA } \\
\hline & $F$ & $\mathrm{gl1} / \mathrm{gl2}$ & Sig. & $F$ & gl1 / gl2 & Sig. \\
\hline me & 0.05 & $2 / 42$ & 0.951 & 1.21 & $2 / 42$ & 0.309 \\
\hline bora & 0.01 & $2 / 42$ & 0.991 & 1.45 & $2 / 42$ & 0.247 \\
\hline borm & 0.08 & $2 / 42$ & 0.921 & 0.02 & $2 / 42$ & 0.977 \\
\hline borp & 1.22 & $2 / 42$ & 0.307 & 0.34 & $2 / 42$ & 0.714 \\
\hline goa & 2.18 & $2 / 42$ & 0.126 & 1.29 & $2 / 42$ & 0.286 \\
\hline go & 0.20 & $2 / 42$ & 0.823 & 0.59 & $2 / 42$ & 0.562 \\
\hline gop & 0.66 & $2 / 42$ & 0.524 & 0.59 & $2 / 42$ & 0.558 \\
\hline ramp & 0.54 & $2 / 42$ & 0.586 & 0.42 & $2 / 42$ & 0.660 \\
\hline rams & 1.83 & $2 / 42$ & 0.173 & 1.21 & $2 / 42$ & 0.307 \\
\hline clp & 3.72 & $2 / 42$ & 0.033 & $1.64^{(1)}$ & $2 / 36.6$ & 0.207 \\
\hline cop & 3.69 & $2 / 42$ & 0.033 & $1.68^{(1)}$ & $2 / 38.7$ & 0.199 \\
\hline $\mathrm{co}$ & 3.06 & $2 / 42$ & 0.058 & 1.16 & $2 / 42$ & 0.323 \\
\hline coa & 2.49 & $2 / 42$ & 0.095 & 1.16 & $2 / 42$ & 0.323 \\
\hline cla & 1.55 & $2 / 42$ & 0.224 & 1.04 & $2 / 42$ & 0.364 \\
\hline rma & 1.83 & $2 / 42$ & 0.173 & 2.51 & $2 / 42$ & 0.094 \\
\hline rmi & 0.41 & $2 / 42$ & 0.663 & 0.64 & $2 / 42$ & 0.532 \\
\hline m2p & 0.24 & $2 / 42$ & 0.789 & 2.66 & $2 / 42$ & 0.082 \\
\hline$m 1 p$ & 4.88 & $2 / 42$ & 0.012 & $8.44^{(1)}$ & $2 / 34.7$ & 0.001 \\
\hline $\mathrm{m} 2 \mathrm{~d}$ & 0.09 & $2 / 35$ & 0.915 & 0.41 & $2 / 35$ & 0.669 \\
\hline $\mathrm{p} 2 \mathrm{~m}$ & 0.23 & $2 / 42$ & 0.794 & 0.47 & $2 / 42$ & 0.627 \\
\hline m1d & 0.50 & $2 / 18$ & 0.614 & 0.43 & $2 / 18$ & 0.655 \\
\hline p1m & 0.45 & $2 / 42$ & 0.639 & 6.52 & $2 / 42$ & 0.003 \\
\hline $\mathrm{cp}$ & 0.30 & $2 / 40$ & 0.745 & 0.54 & $2 / 40$ & 0.588 \\
\hline iip & 1.02 & $2 / 40$ & 0.370 & 3.35 & $2 / 40$ & 0.045 \\
\hline
\end{tabular}

(1) The analysis of variance (ANOVA) was replaced by Brown and Forsythe statistical due to the heterogeneity of variances.

The comparative results between the 3 groups analyzed show that the mandibular body showed growth in the vertical direction, without statistical significance, suggesting that Balters bionator did not influenced this growth. These results corroborate with Kessner and Faltin ${ }^{18}$ because there is a joint remodeling that promotes mandibular adaptation more to anterior without changing mandibular length significantly. Schulhof and Engel, ${ }^{29}$ disagree with these findings and emphasize that treatment with the bionator appliance promotes an increase in ascending ramus and mandibular body in relation to normal growth.

In the present study there was no significant increase in mandibular ramus because the condyle grew up to $1.68 \mathrm{~mm}(\mathrm{c}), 2.27 \mathrm{~mm}(\mathrm{~g} 1)$ and $2.68 \mathrm{~mm}(\mathrm{~g} 2)$ and gonion grew in the same direction, from
Table 8 - Means and standard deviations of tooth eruption and results of multiple comparison tests of mean measures that showed a significant result in the ANOVA.

\begin{tabular}{cccc}
\hline \multirow{2}{*}{ Point } & Control Group & Group 1 & Group 2 \\
\cline { 2 - 4 } & Mean \pm SD & Mean \pm SD & Mean \pm SD \\
m1p & $2.19^{\mathrm{a}} \pm 1.14$ & $3.11^{\mathrm{a}} \pm 1.93$ & $4.83^{\mathrm{b}} \pm 2.52$ \\
p1m & $2.67^{\mathrm{a}} \pm 2.15$ & $3.21^{\mathrm{a}} \pm 2.22$ & $5.35^{\mathrm{b}} \pm 2.40$ \\
iip & $1.52^{\mathrm{a}} \pm 0.80$ & $2.70^{\mathrm{b}} \pm 1.31$ & $1.90^{\mathrm{ab}} \pm 1.12$ \\
& & Horizontal displacement & \\
iip & $0.72^{\mathrm{a}} \pm 0.84$ & $1.86^{\mathrm{b}} \pm 1.09$ & $0.40^{\mathrm{a}} \pm 1.55$ \\
& & Vertical displacement & \\
m2p & $-1.16^{\mathrm{a}} \pm 1.00$ & $-0.92^{\mathrm{a}} \pm 1.12$ & $-2.37^{\mathrm{b}} \pm 1.35$ \\
m1p & $-1.85^{\mathrm{a}} \pm 1.16$ & $-2.66^{\mathrm{a}} \pm 2.28$ & $-4.64^{\mathrm{b}} \pm 2.68$ \\
p1m & $-1.84^{\mathrm{a}} \pm 1.16$ & $-2.66^{\mathrm{a}} \pm 2.28$ & $-4.64^{\mathrm{b}} \pm 2.68$ \\
\hline
\end{tabular}

Note: Different letters correspond to statistically different averages by StudentNewman-Keuls (SNK) test

$0.86 \mathrm{~mm}(\mathrm{c}), 1.32 \mathrm{~mm}(\mathrm{~g} 1)$ and $1.27 \mathrm{~mm}(\mathrm{~g} 2)$, resulting in a small increase in the co-go distance, respectively of $0.82 \mathrm{~mm}$ for the Control group, $0.95 \mathrm{~mm}$ for Group 1 and $1.41 \mathrm{~mm}$ for Group 2. The results found by Reis et al, ${ }^{27}$ were similar to ours, where Balters bionator stimulated the growth of the mandibular body and ramus similarly in both age groups without modifying the tendency of individual growth. Moreover, Malta et $\mathrm{a} \mathrm{l}^{19}$ showed that the difference in amount of mandibular growth occurs and is significant $(3.3 \mathrm{~mm})$ when comparing cases of Class II patients treated with Balters bionator appliance and untreated, demonstrating that this appliance is efficient.

The data show that the gonion region exhibited significant changes in all studied groups. The points goa, go and gop showed significant upward and backward displacement except for goa in Group 1. The displacement of these points in Group 2 was higher than in other groups, but without statistical significance. These results point to a pattern of remodeling gonion region, especially in mature children, compatible with the natural growth demonstrated by several authors, ${ }^{8,9,10,14}$ who observed resorption in the mandible posterior border. So, part of the vertical growth seen in the condylar region is partially offset by reabsorption which occurs in the gonion region, resulting in small changes in mandibular ramus height. Bigliazzi, Kessner and Faltin Jr., ${ }^{7}$ found that in Class II, division 1, patients with mandibular retrognathia, the gonion angle remained unchanged during the treatment period with bionator. 
Clinical observations have shown that the use of orthopedic devices can alter the growth of the mandible, however the exact nature of this change remains a topic of great controversy. ${ }^{13}$ Our results showed that in the Control group there was a significantly downward movement of menton and that the mandibular border exhibited backward movement without statistical significance. These data are consistent with other studies, ${ }^{14,30}$ which found bone apposition in the anterior portion of the mandibular border.

In Group 1 occurred forward and downward displacement of the mentum and anterior border, while the posterior border had a backward and upward movement, all insignificant. In Group 2, the mentum presented downward movement and the posterior border a significant backward movement and nothing significant of the anterior and middle border. These data indicate a relative stability of the mandibular lower border, mainly in young children.

The results observed for mature children were similar to the Control group, results that are in accordance with other studies. ${ }^{20,21}$ On the other hand, Almeida, ${ }^{1}$ who treated children aged 10.8 months observed an increase in mandibular protrusion and the effective length of the mandibular body, which according to Almeida-Pedrin, ${ }^{2}$ promoted a significant improvement in the maxillomandibular relationship compared to the Control group, which agrees with the study of Basciftci et $\mathrm{al},{ }^{5}$ in the same year, that the greatest amount of growth occurs during adolescence.

Opheij et $\mathrm{al}^{26}$ did not find statistical significant skeletal changes in Class II malocclusion patients with mandibular retrognathia, treated with bionator, noticing the most significant effects on the dentoalveolar structures. For Janson ${ }^{17}$ children treated in the pre-pubertal period exhibited dentoalveolar changes, notably a protrusion of the lower incisors and correction of molar relationship in distal-occlusion. It was observed $^{17}$ an overjet reduction of approximately $2 \mathrm{~mm}$, similar to what was observed in our study (significant overjet decrease in $1.86 \mathrm{~mm}$ in Group 1, compared with $0.72 \mathrm{~mm}$ in the Control group and $0.4 \mathrm{~mm}$ in Group 2). For Bastos and Mucha, ${ }^{6}$ one of the bionator indications is when there is a possibility of backward projection of the lower incisors. For Martins ${ }^{21}$ skeletal changes promoted by bionator occur in $32 \%$ through increased lower facial height and $68 \%$ dentoalveolar movement, higher of lower molars and upper incisors.

In the vertical direction occurred greater amount of eruption of posterior teeth, significant for Group 2 that showed nearly twice eruption of molars $(2.37 \mathrm{~mm}$ of the first molars, $4.64 \mathrm{~mm}$ of second molars and $2.66 \mathrm{~mm}$ of the first premolars) when compared to the Control group and Group 1. These facts demonstrate that the bionator appliance with occlusal support allows the active eruption of permanent molars. With respect to premolars, these erupt in more mature individuals (Group 2), mainly due to more advanced stage of root formation that they are. For the authors ${ }^{1,11}$ there was a significant increase in posterior facial height especially in the treated group with bionator by extrusion of posterior teeth, confirmed by our study when considering the results of the more mature group (Group 2) and the youngest (Group 1), which demonstrated the predominance of dentoalveolar adaptation in the horizontal direction.

\section{CONCLUSION}

Due to the methodology adopted in this study and the results, based on statistical analysis, we conclude that:

1 - When it was evaluated the skeletal and dental changes in groups individually, there was growth at all points analyzed.

2 - When the groups were compared with each other, skeletal mandibular changes were similar indicating that the mandibular growth pattern has not changed significantly with the established treatment and.

3 - When it was evaluated dental changes after using bionator, a greater extrusion of the first permanent molars and premolars in more mature group (Group 2) and the labial inclination of the lower incisors was higher in younger patients (Group 1). 
1. Almeida MR. Avaliação cefalométrica comparativa da interceptação da má-oclusão de Classe II, divisão 1, utilizando o aparelho de Frankel e o bionator de Balters [tese]. Bauru (SP): Universidade de São Paulo; 2000

2. Almeida-Pedrin RR. Efeitos cefalométricos do aparelho extrabucal conjugado (Splint Maxilar) e do bionator, no tratamento de má oclusão de Classe II, divisão 1 [tese]. Bauru (SP): Universidade de São Paulo; 2003.

3. Araujo AM. Estudo cefalométrico com implantes metálicos dos efeitos do aparelho Bionator de Balters no desenvolvimento esquelético maxilomandibular durante o tratamento da má oclusão Classe II, divisão 1 [tese]. Araraquara (SP): Universidade Estadual Paulista; 2003.

4. Balters W. Guía de la técnica del Bionator. Buenos Aires: Editorial Mundi; 1969. 68 p.

5. Basciftci FA, Uysal T, Büyükerkmen A, Sari Z. The effects of activator treatment on the craniofacial structures of Class II, division 1 patients Eur J Orthod. 2003:25(1):83-7

6. Bastos GK, Mucha JN. Aparelhos funcionais: uma revisão. Rev Bras Odontol. 2002:59(3):184-8.

7. Bigliazzi R, Kessner CA, Faltin Jr K. Estudo das alterações anatômicas e morfológicas em pacientes em Classe II, divisão 1, com retrognatismo mandibular, tratados com bionator de Balters, empregando-se a análise das contra-partes de Enlow. Rev Dental Press Ortod Ortop Facial. 2000;5(2):9-19

8. Björk A. Facial growth in man, studied with aid of metallic implants. Acta Odontol Scand. 1955:13(1):9-34.

9. Björk A, Skieller V. Normal and abnormal growth of the mandible. A synthesis of longitudinal cephalometric implant studies over a period of 25 years. Eur J Orthod. 1983:5(1):1-46.

10. Buschang PH, Gandini Jr L. G. Mandibular skeletal growth and modelling between 10-15 years. Eur J Orthod. 2001:23:1-11

11. Cavalcante CT. Alterações verticais decorrentes da interceptação da Classe II com o aparelho Bionator [tese]. Bauru (SP): Universidade de São Paulo: 2003.

12. Almeida MR, Henriques JF, Ursi W. Comparative study of the Frankel (FR-2) and bionator appliances in the treatment of Class II malocclusion. Am J Orthod Dentofacial Orthop. 2002;121(5):458-66.

13. Graber TM, Neumann B. The Bionator removable orthodontic appliances. Philadelphia: Saunders Company; 1977.

14. Gu Y, McNamara JA Jr. Mandibular growth changes and cervical vertebral maturation. Angle Orthod. 2007:77(6):947-53.

15. Hultgren BW, Isaacson RJ, Erdman AG, Worms FW. Mechanics, growth, and class II corrections. Am J Orthod. 1978;74(4):338-95.

16. Iseri $\mathrm{H}$, Solow $\mathrm{B}$. Change in the width of the mandibular body from 6 to 23 years of age: an implant study. Eur J Orthod. 2000:22(3):229-38.

17. Janson I. A cephalometric study of the efficiency of the Bionator. Trans Eur Orthod. Soc. 1977:53:283-93.
18. Kessner CA, Faltin Jr K. Estudo cefalométrico radiográfico sobre a influência do Bionator de Balters no crescimento mandibular e o incremento vertical do ramo ascendente da mandíbula, nos tratamentos das más oclusões de Classe II, divisão I com retrognatismo mandibular. Rev Inst Ciênc Saúde. 1997:15(esp. issue):51-8

19. Malta LA, Baccetti T, Franchi L, Faltin K, McNamara JA. Long-term dentoskeletal effects and facial profile changes induced by bionator therapy. Angle Orthod. 2010;80(1):10-7.

20. Maltagliati LA, Henriques JFC, Janson G, Almeida RR, Freitas MR. A influência do tratamento ortopédico nas estruturas faciais de individuos com má oclusão de Classe II, 1a divisão. Um estudo comparativo. J Appl Oral Sci. 2004:12(2):164-70

21. Martins RP, Rosa Martins JC, Martins LP, Buschang PH. Skeletal and dental components of Class II correction with the bionator and removable headgear splint appliances. Am J Orthod Dentofacial Orthop. 2008:134(6):732-41.

22. MCNamara JA Jr, Carlson DS. Quantitative analysis of temporomandibular joint adaptations to protrusive function. Am J Orthod. 1979;76(6):593-61.

23. Melo ACM, Gandini Jr LG, Santos-Pinto A, Araújo AM, Gonçalves JR. Avaliação cefalométrica do efeito do tratamento da má oclusão Classe II, divisão 1, com o bionator de Balters: estudo com implantes metálicos Rev Dental Press Ortod Ortop Facial. 2006;11(3):18-31

24. Melo ACM, Santos-Pinto A, Martins JCR, Martins LP, Sakima MT. Orthopedic and orthodontic component of Class II division 1 malocclusion correction with Balters bionator: a cephalometric study with metallic implants. World J Orthod. 2003:4:237-42.

25. Monini AC. Estudo cefalométrico com implantes metálicos das alterações esqueléticas, a longo prazo, após o uso do Bionator de Balters [tese]. Araraquara (SP): Universidade Estadual Paulista; 2008.

26. Opheij DG, Callaert H, Opdebeeck HM. The effect of the amount of protrusion built into the bionator on condylar growth and displacement: a clinical study. Am J Orthod Dentofacial Orthop. 1989;95(5):401-9.

27. Reis SAB, Moresca R, Goldenberg FC, Vigorito JW. Utilização da análise de Jarabak para a avaliação do tratamento da Classe II, divisão 1, com o Bionator de Balters. Ortodontia. 2000;33(2):42-52

28. Ruf S, Pancherz H. Temporomandibular joint growth adaptation in Herbst treatment a prospective magnetic resonance imaging and cephalometric roentgenographic study. Eur J Orthod. 1998:20(4):375-88.

29. Schulhof RJ, Engel GA. Results of Class II to functional appliance treatment. J Clin Orthod. 1982;16(9):587-99.

30. Wang MK, Bushang PH, Behrents R. Mandibular rotation and remodeling changes during early childhood. Angle Orthod. 2009;79(2):271-5. 